\title{
Analisis Regresi Linier dengan IBM SPSS Statistics
}

\author{
Wufron \\ Universitas Garut \\ wufron@uniga.ac.id
}

\begin{abstract}
Abstrak
Tulisan ini menjelaskan tentang Analisis Regresi Linier dengan menggunakan IBM SPSS Statistics. Proses pengolahan Regresi Linier Sederhana dan Berganda dijelaskan secara sistematis. Program aplikasi SPSS yang digunakan pada pengolahan ini adalah IBM SPSS Statistics Versi 20. Penggunaan suatu program aplikasi pengolahan data dapat membuat semakin efektif proses pengolahan data sehingga mempermudah dalam analisa dari hasil pengolahan yang dilakukan. Hasil penulisan menjelaskan terdapat tujuh tahapan dalam pengolahan data dengan analisis regresi linier sederhana dan berganda dengan beberapa tabel output yang akan digunakan sebagai bahan untuk interpretasi atau analisis hasil pengolahan data.
\end{abstract}

Kata Kunci: Analisis Regresi Linier, SPSS

\section{Pendahuluan}

Aktivitas akademis dan pekerjaan tidak akan lepas dari pengolahan angka. Pengolahan data biasa dilakukan untuk riset, pelaporan hasil kerja atau sekedar penyajian data menjadi tabel, grafik atau ukuran-ukuran lain dari data. Penyajian data dalam bentuk tabel dan grafik dilakukan agar menyampaikan informasi dari data dapat dilakukan secara efektif (Suharyadi, 2013). Para akademis biasa melakukan pengolahan data ketika melaksanakan aktivitas perkuliahan atau tugas-tugas yang berkaitan dengan proses pengolahan data seperti halnya riset. Dunia kerja seringkali membutuhkan pengolahan data untuk merubah data mentah pada perusahaan menjadi suatu bentuk penyajian yang lebih efektif seperti tujuan pelaporan atau bahan evaluasi kinerja yang telah dicapai.

Proses pengolahan data untuk saat ini tidak dapat dilakukan cara manual artinya dilakukan dengan tidak menggunakan alat bantu pengolahan seperti program aplikasi apapun. Tentu hal ini akan memperlambat proses pengolahan data yang berimbas terhadap tidak efektifnya pekerjaan yang sedang berlangsung. Pelajar dalam mengerjakan tugas riset tidak dapat menginterpretasikan hasil pengolahan data dengan cepat sehingga dapat memperlambat proyek risetnya karena harus menghitung secara rumus-rumus manual setiap tahapan pengolahan data. Seorang praktisi tidak dapat dengan cepat mendapatkan hasil interpretasi dari kinerja pada periode sebelumnya atau tidak dapat merencanakan pencapaian pada periode yang akan datang dengan efektif untuk saat ini tanpa adanya alat bantu dalam proses pengolahan data.

Saat ini penulis fokus pada suatu hal yang sering dihadapi pelajar pemula dalam setiap tugas mata kuliah atau riset yang sedang dilaksanakan yaitu bagaimana pengolahan data dengan menggunakan suatu program aplikasi salah satunya IBM SPSS versi 20 digunakan untuk mengetahui hubungan antar variabel atau pengaruh dari satu atau beberapa variabel independen terhadap variabel dependen dengan menggunakan analisis regresi linier sederhana dan regresi linier berganda. Analisis regresi linier merupakan metode statistika yang digunakan untuk menganalisis pengaruh langsung dari satu atau beberapa variabel independen terhadap suatu variabel independen (Sulianto, 2011), sedangkan SPSS (Statistical Package for the Social Science) merupakan program aplikasi yang digunakan untuk data editor, viewer, multidimensional Pivot Tables, High Resolution Graphics, Data Transformations dll (Zein, 2019). 


\section{Metode}

Metode pembahasan yang digunakan berupa penjelasan mengenai proses pengolahan data serta hasil Analisis Regresi Linier Sederhana dan Berganda menggunakan Program Aplikasi SPSS versi 20.

\section{Pembahasan}

\subsection{Proses Pengolahan Data Penelitian}

Tahap pertama, membuka aplikasi SPSS

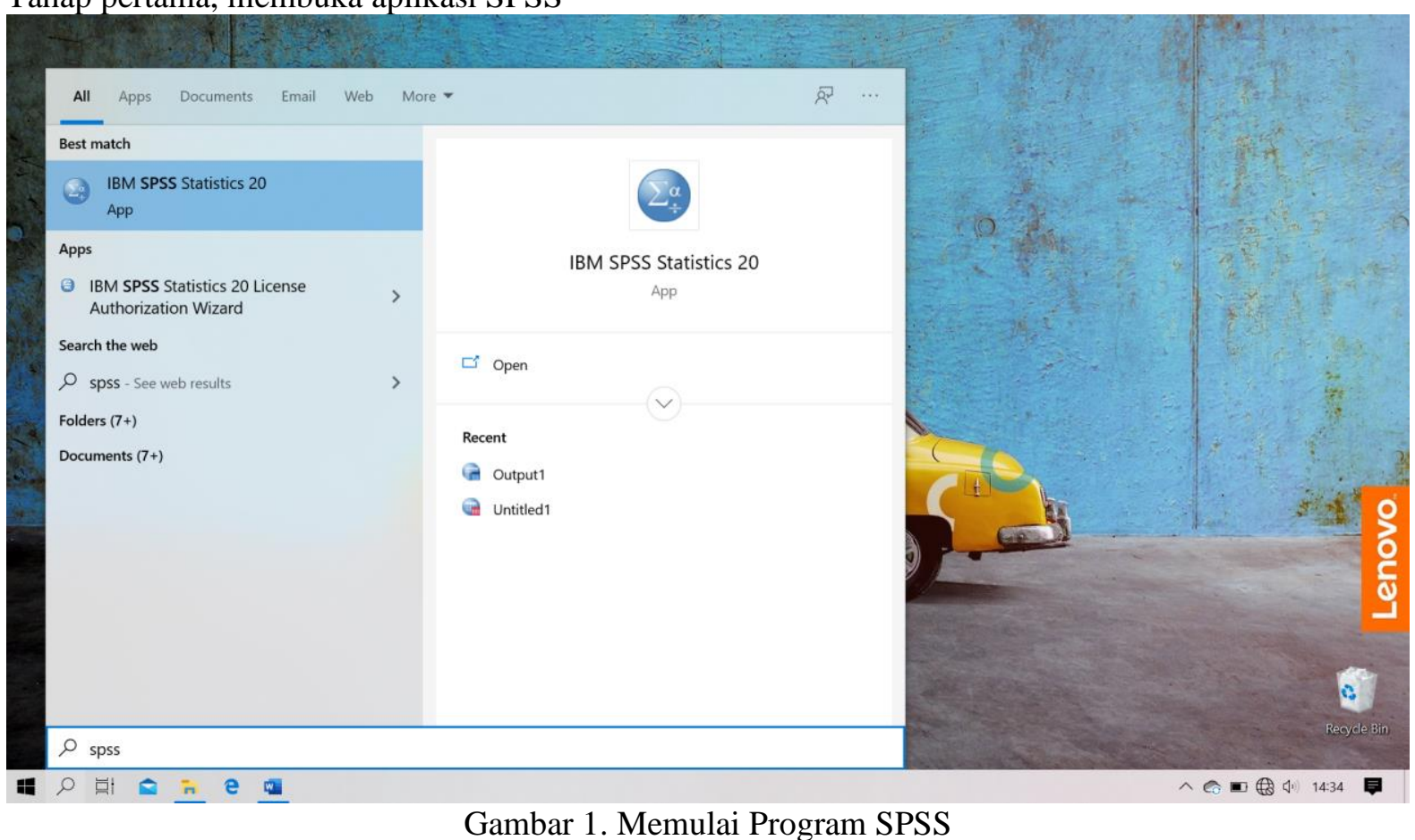

Tahap kedua, memulai aplikasi dari membuat data baru, klik Cancel

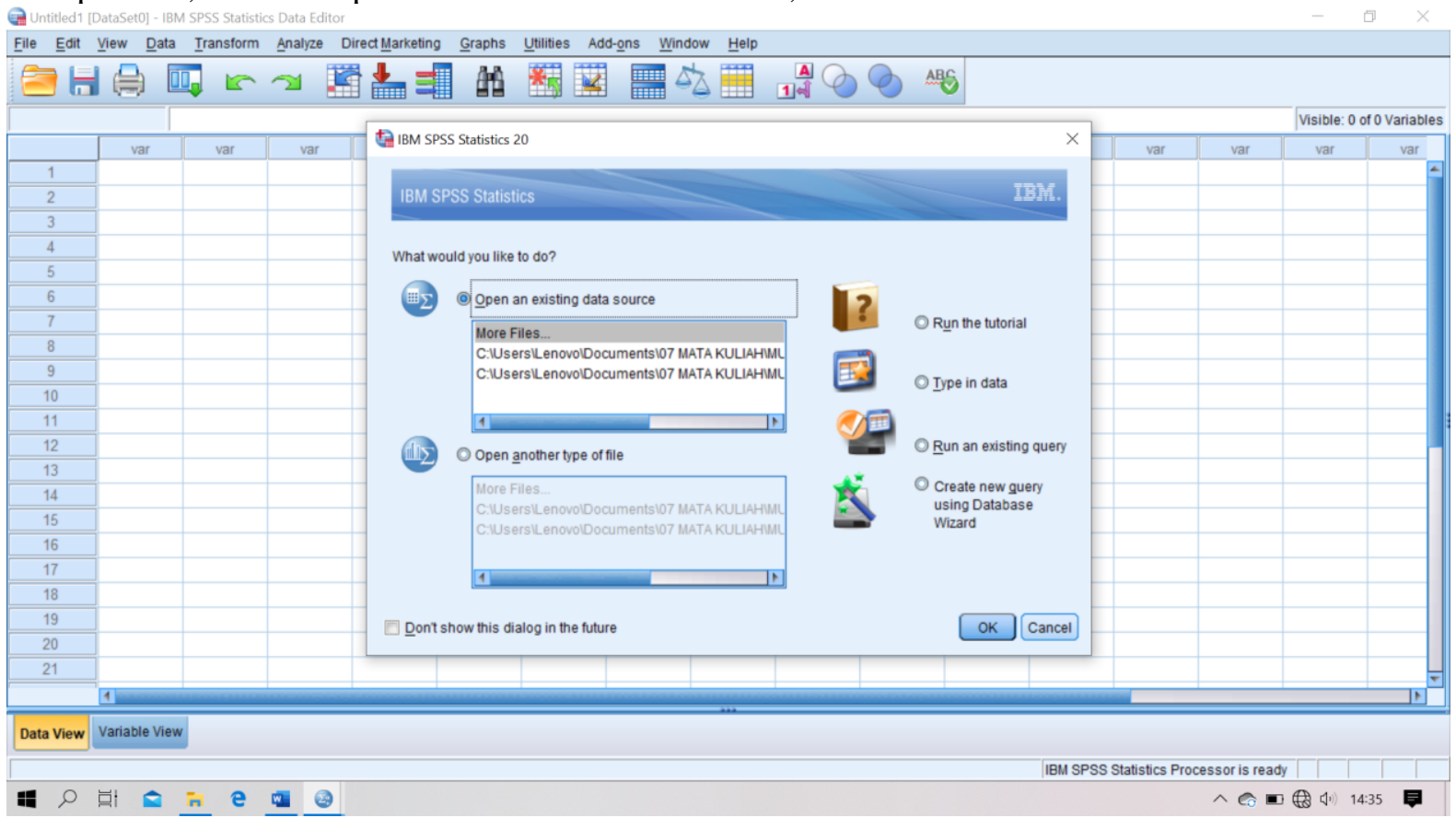


Gambar 2. Tampilan Depan SPSS

Tahap ketiga, menyiapkan pengaturan data. Klik Variable View

Isi kolom Name dengan singkatan dari setiap nama variabel penelitian

Isi kolom Type dengan jenis data penelitian

Isi kolom Width sesuai dengan lebar atau panjang digit data

Isi kolom Decimals sesuai dengan banyak desimal setiap data penelitian

Isi kolom Label dengan nama lengkap setiap variabel penelitian

Isi kolom Values untuk interpretasi label data nominal dan ordinal, jika data penelitian interval dan rasio tidak perlu diisi

Isi kolom Missing jika terdapat data periodik yang hilang

Isi kolom Columns sesuai dengan panjang tampilan data yang diinginkan pada Data View

Pilih Align sesuai keinginan

Isi kolom Measure sesuai dengan jenis skala data

Isi kolom Role sesuai dengan jenis variabel penelitian

Jika Analisis Regresi Linier Sederhana maka tampilan Variable View sebagai berikut

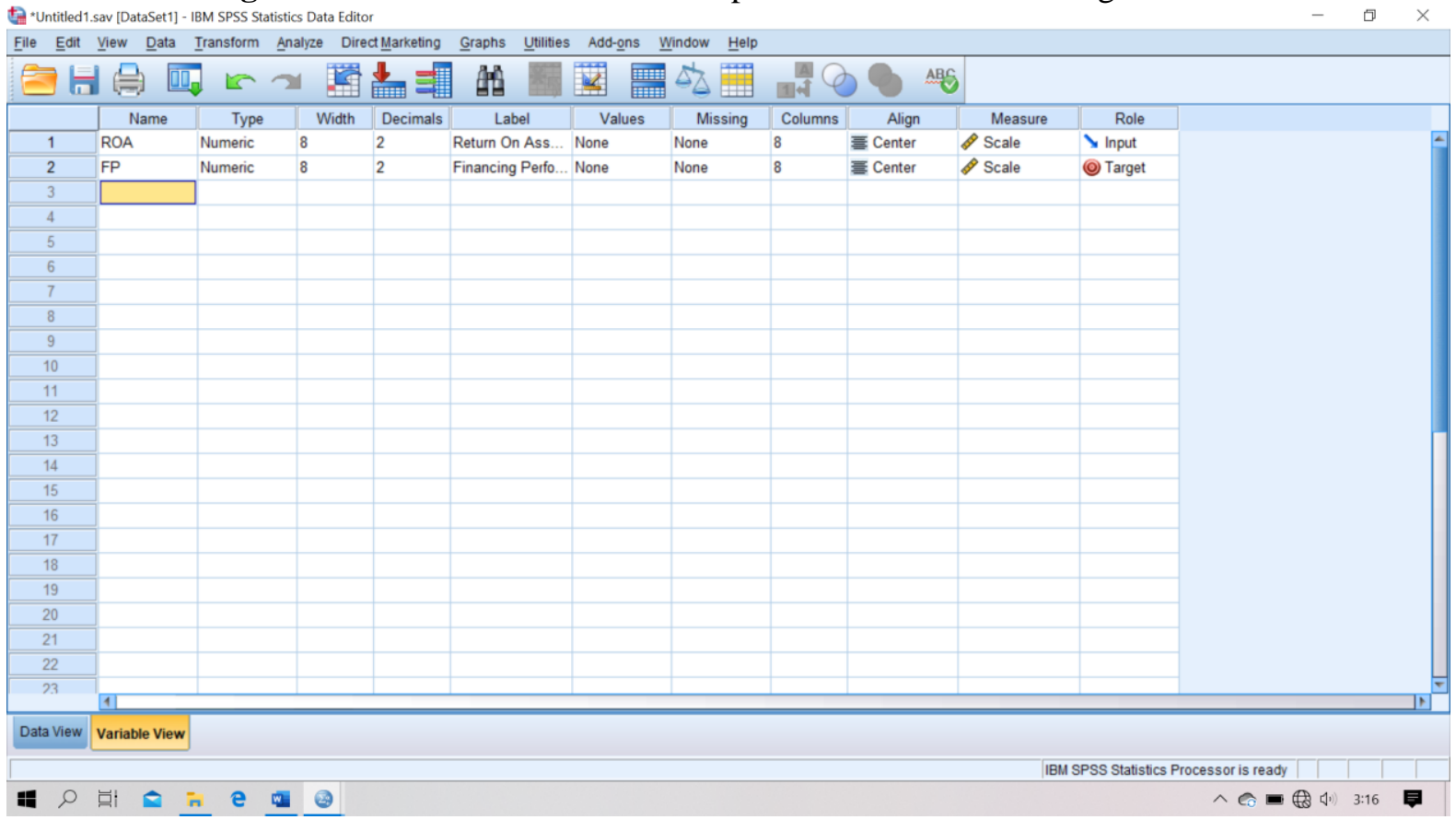

Gambar 3. Setting Variable View Regresi Linier Sederhana 
Jika Analisis Regresi Linier Berganda maka tampilan Variable View sebagai berikut

t. Untitled1 [DataSet0] - IBM SPSS Statistics Data Editor

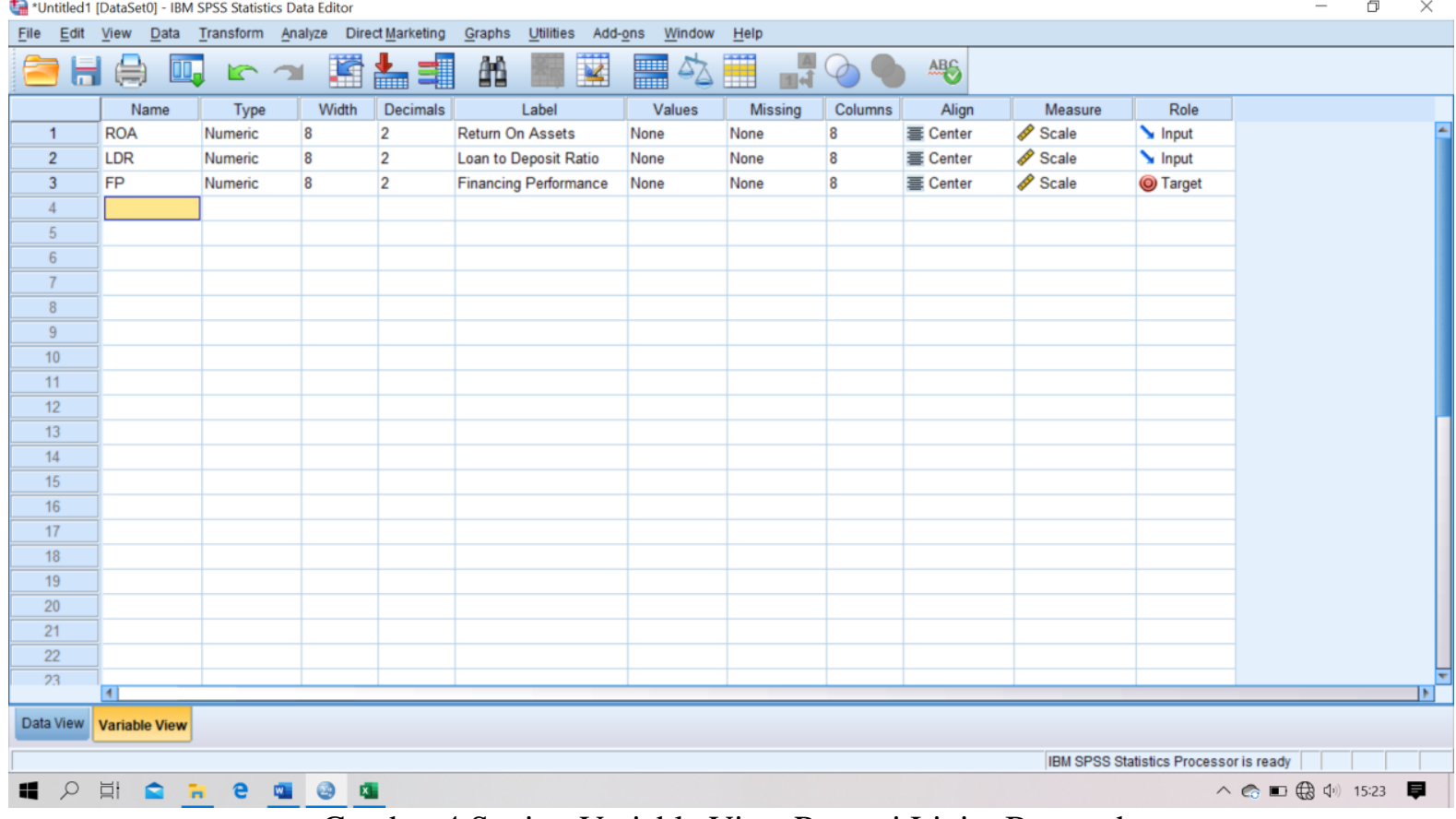

Gambar 4 Setting Variable View Regresi Linier Berganda

Tahap keempat, entry data setiap variabel penelitian

Jika Analisis Regresi Linier Sederhana maka tampilan Data View sebagai berikut

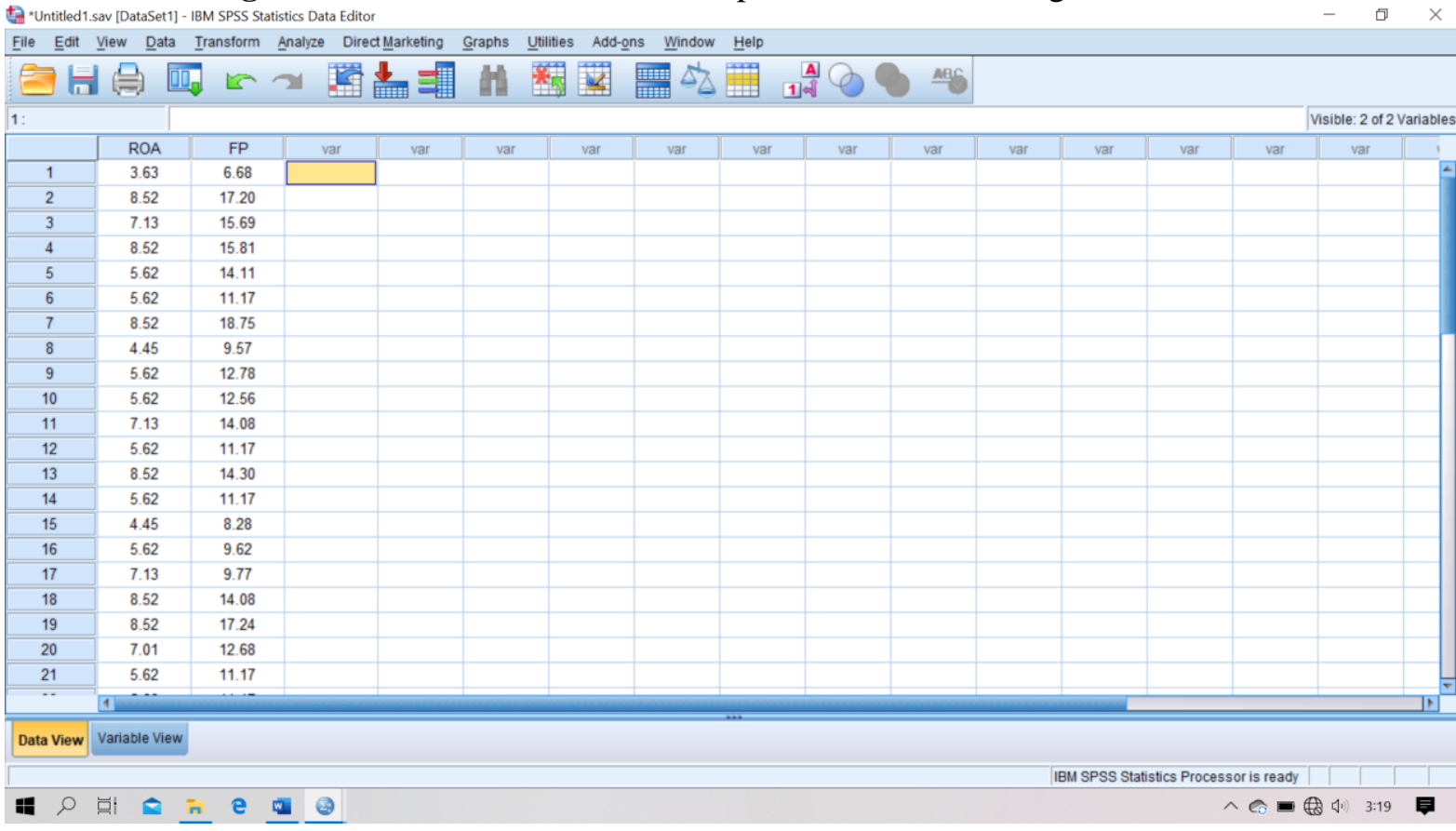

Gambar 5. Entry Data Regresi Sederhana 
Jika Analisis Regresi Linier Berganda maka tampilan Data View sebagai berikut

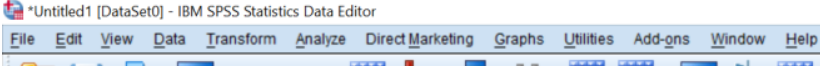

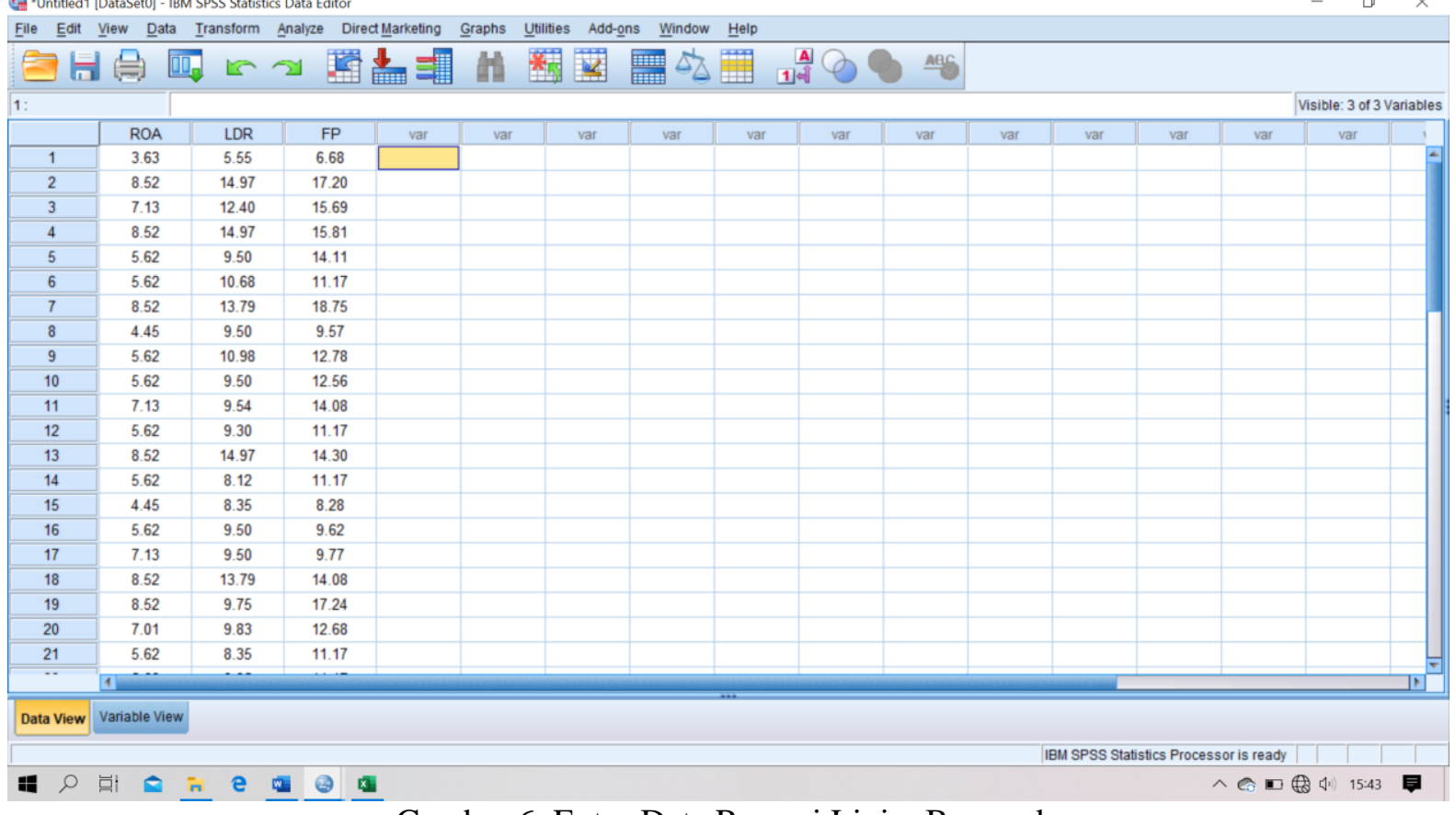

Gambar 6. Entry Data Regresi Linier Berganda

Tahap Kelima, proses memilih metode

Pilih menu Analyze, lalu klik Regression dan klik Linear untuk memilih Regresi Linear baik sederhana atau berganda pada tahap ini sama

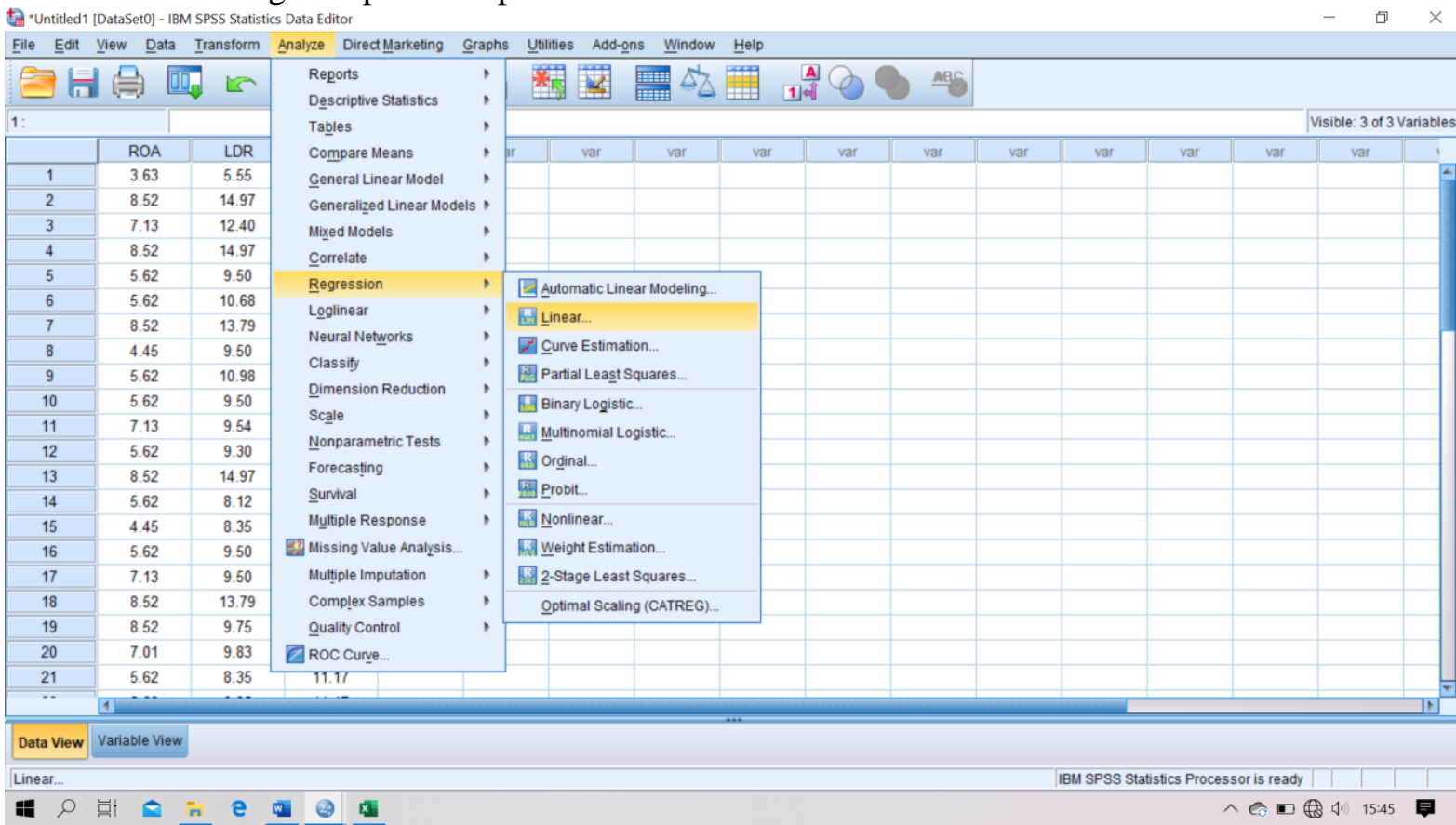

Gambar 7. Proses Regression 
Tahap keenam, memasukan semua variabel penelitian baik variabel Independen atau variabel dependen Lalu klik Ok

Jika Analisis Regresi Linier Sederhana maka tampilan Kotak Dialog sebagai berikut

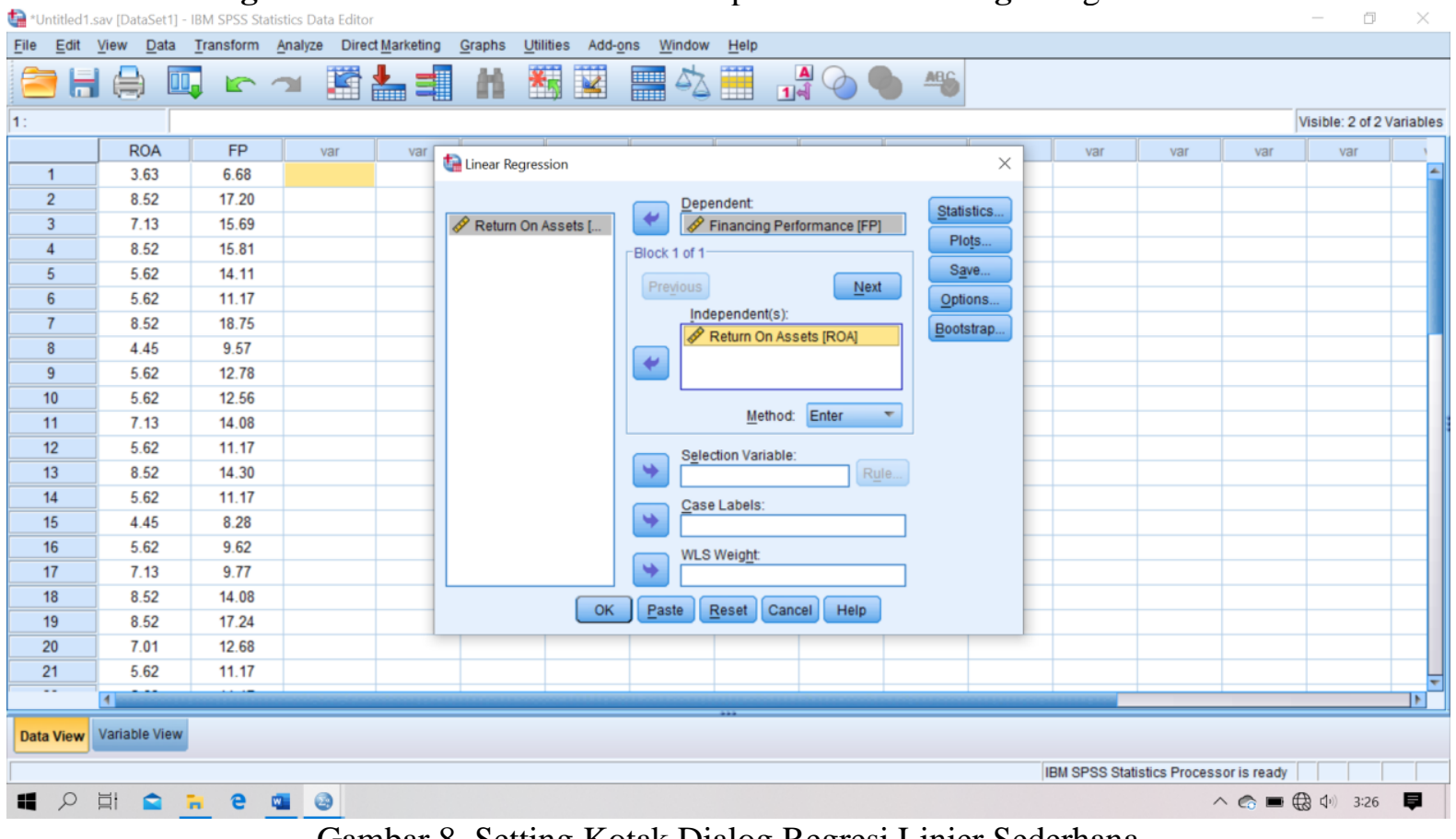

Gambar 8. Setting Kotak Dialog Regresi Linier Sederhana

Jika Analisis Regresi Linier Berganda maka tampilan Kotak Dialog sebagai berikut

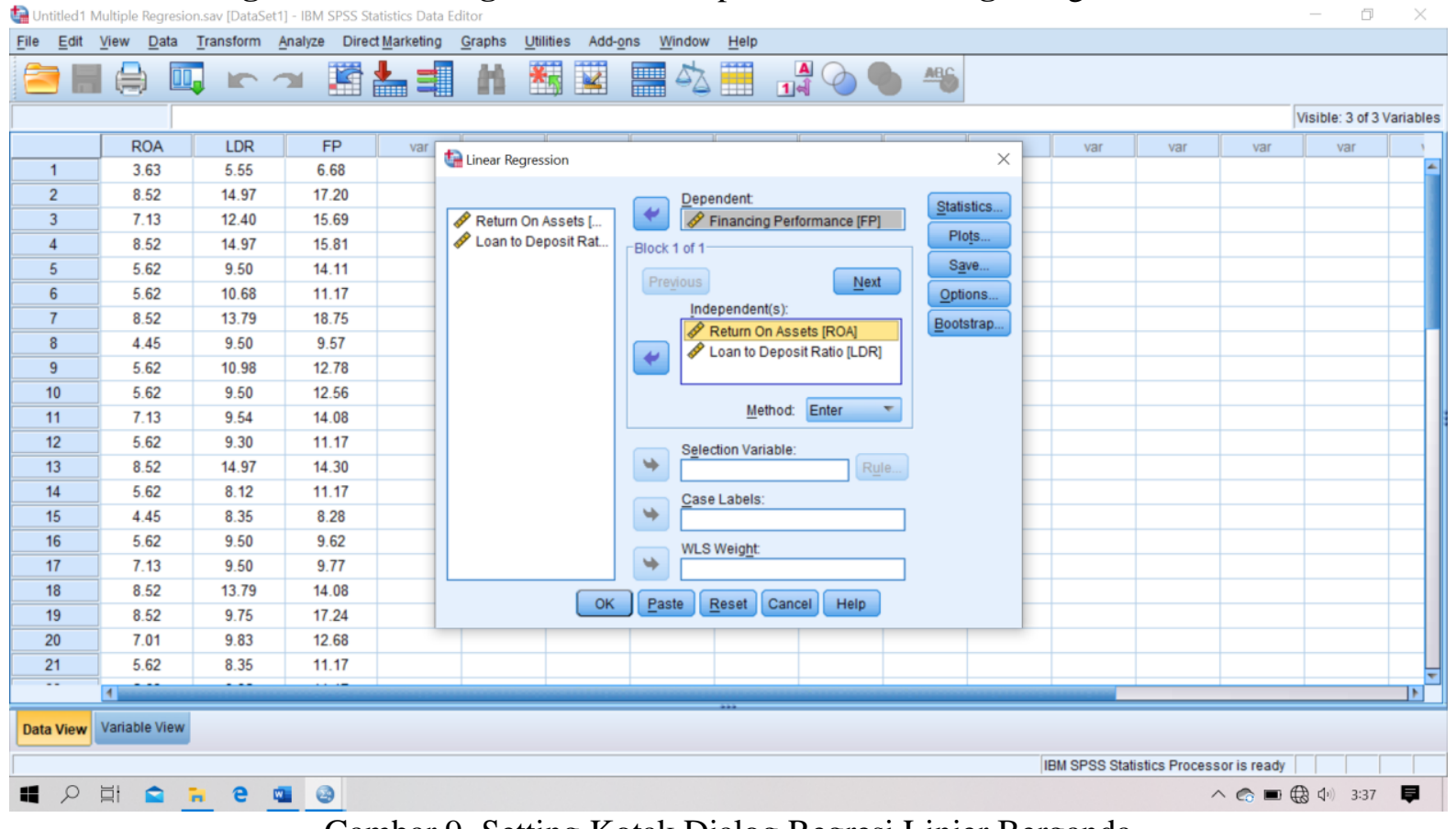

Gambar 9. Setting Kotak Dialog Regresi Linier Berganda 
Tahap ketujuh, muncul output hasil pengolahan

Jika Analisis Regresi Linier Sederhana maka tampilan Output sebagai berikut

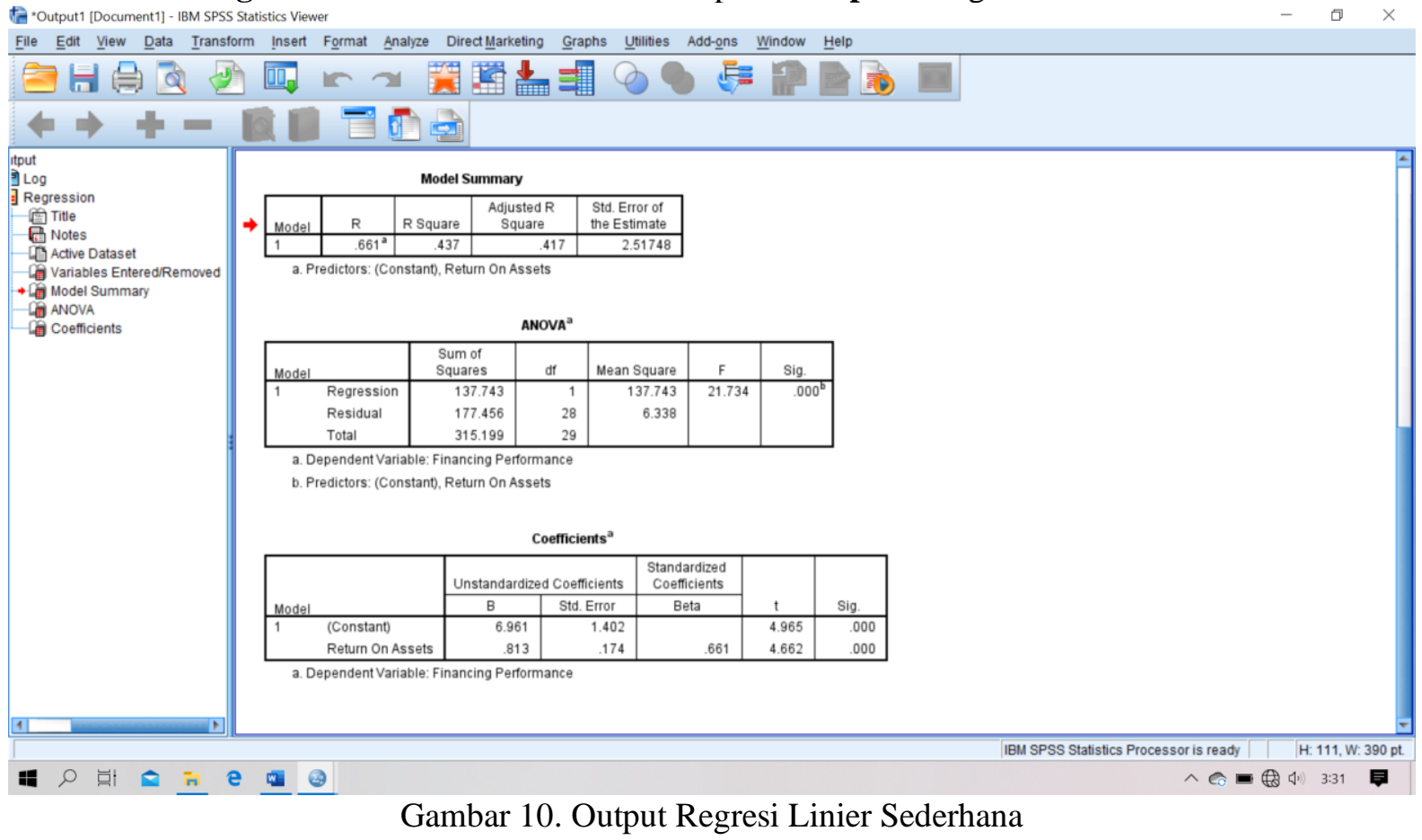

Jika Analisis Regresi Linier Berganda maka tampilan Output sebagai berikut

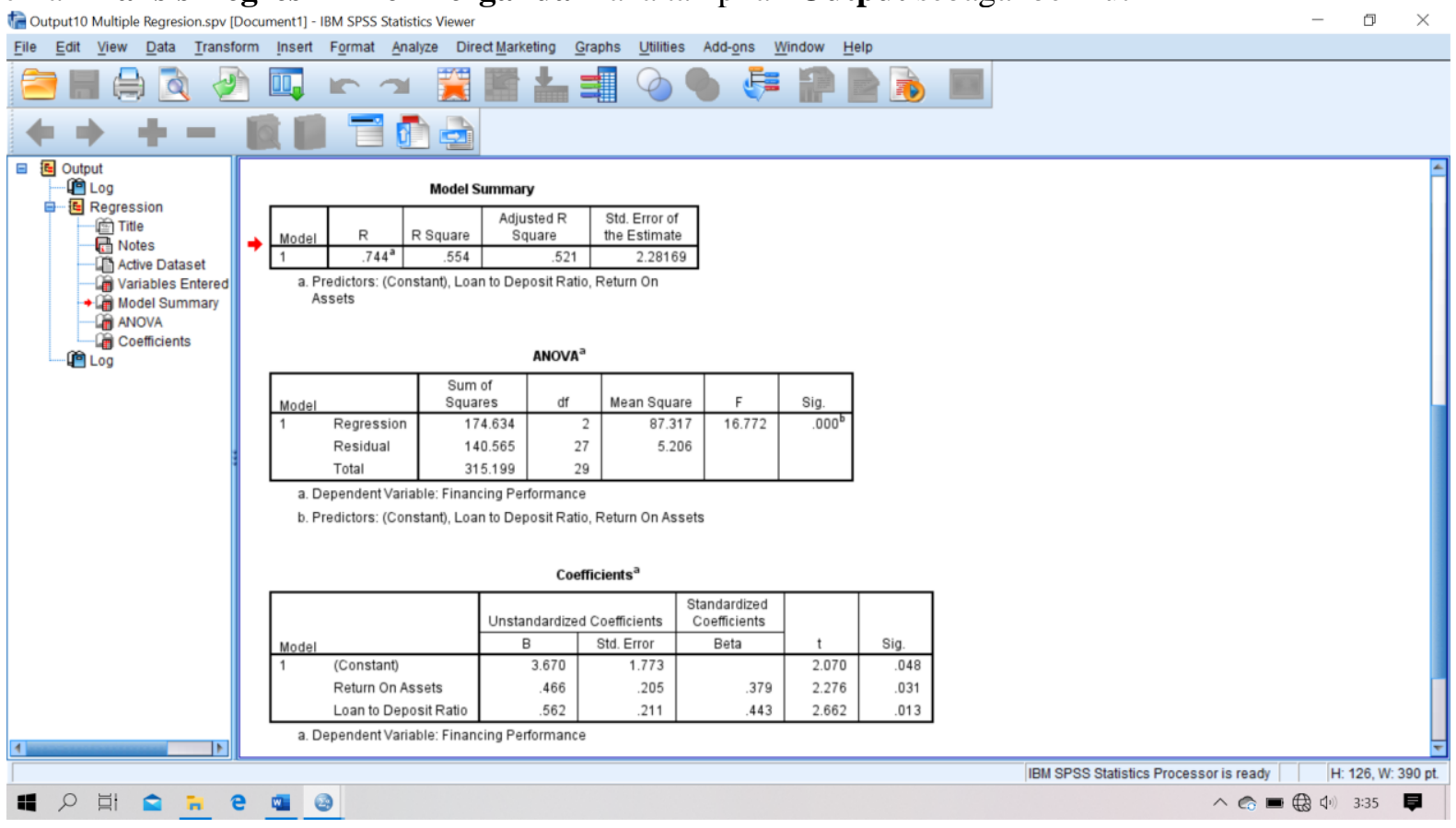

Gambar 11. Output Regresi Linier Berganda

\subsection{Interpretasi Output Data Penelitian}

Setelah proses pengolahan selesai dilakukan, maka pada Analisis Regresi Sederhana hanya perlu dianalisis dua tabel utama yaitu Model Summary dan Coefficients sedangkan pada Analisis Regresi Berganda akan dianalisis tiga tabel utama yaitu tabel Model Summary, ANOVA dan Coefficients dimana masing-masing tabel dapat dianalisis sebagai berikut. 


\subsubsection{Interpretasi Output Analisis Regresi Linier Sederhana}

Tabel 1. Model Summary Simple Regression

\begin{tabular}{|l|r|r|r|c|}
\hline Model & R & R Square & $\begin{array}{c}\text { Adjusted R } \\
\text { Square }\end{array}$ & $\begin{array}{c}\text { Std. Error of the } \\
\text { Estimate }\end{array}$ \\
\hline 1 & $.661^{\mathrm{a}}$ & .437 & .417 & 2.51748 \\
\hline
\end{tabular}

Pada tabel di atas didapat nilai $\mathbf{R}$ Square atau $\mathrm{R}^{2}$, dimana $\mathrm{R}$ Square adalah nilai yang menunjukkan persentase sumbangan variabel independen dalam mempengaruhi variabel dependen sedangkan sisanya dipengaruhi variabel lain atau epsilon yang disimbolkan $\varepsilon_{\mathrm{i}}$. $\mathrm{R}$ Square didapat nilai sebesar 0,437 artinya besarnya sumbangan variabel independen dalam mempengaruhi variabel dependen adalah sebesar $43,7 \%$ sedangkan sisanya 56,3\% dipengaruhi oleh variabel lain.

Tabel 2. Coefficients ${ }^{\text {a }}$ Simple Regression

\begin{tabular}{|c|c|c|c|c|c|c|}
\hline \multirow{2}{*}{\multicolumn{2}{|c|}{ Model }} & \multicolumn{2}{|c|}{ Unstandardized Coefficients } & \multirow{2}{*}{$\begin{array}{c}\text { Standardized } \\
\text { Coefficients } \\
\text { Beta }\end{array}$} & \multirow[t]{2}{*}{$\mathrm{t}$} & \multirow[t]{2}{*}{ Sig. } \\
\hline & & B & Std. Error & & & \\
\hline \multirow{2}{*}{1} & (Constant) & 6.961 & 1.402 & & 4.965 & .000 \\
\hline & Return On Assets & .813 & .174 & .661 & 4.662 & .000 \\
\hline
\end{tabular}

a. Dependent Variable: Financing Performance

Melalui tabel tersebut dapat disusun persamaan regresi dengan nilai Constant dan coefficient variabel X pada kolom B serta dianalisis nilai sig variabel X. Persamaan regresi adalah sebagai berikut:

$$
Y=6,961+0,813 X
$$

Didapat nilai constant sebesar 6,961 artinya secara statistik tanpa adanya X maka besarnya Y adalah 6,961.

Didapat nilai coefficient variabel $\mathbf{X}$ sebesar 0,813 artinya besarnya pengaruh $\mathrm{X}$ terhadap $\mathrm{Y}$ sangat kuat karena memiliki persentase sebesar $81,3 \%$ jika melihat tabel berikut:

Tabel 3. Interval Koefisien Regresi

\begin{tabular}{|c|c|}
\hline Interval & Keterangan \\
\hline$\geq 80,00 \%$ & Sangat Kuat \\
\hline $60,00 \%-79,99 \%$ & Kuat \\
\hline $40,00 \%-59,99 \%$ & Cukup Kuat \\
\hline $20,00 \%-39,99 \%$ & Lemah \\
\hline$\leq 19,99 \%$ & Sangat Lemah \\
\hline
\end{tabular}

Didapat nilai coefficient variabel $\mathbf{X}$ positif artinya $\mathrm{X}$ berpengaruh positif terhadap $\mathrm{Y}$, semakin tinggi $\mathrm{X}$ maka $\mathrm{Y}$ semakin tinggi dan sebaliknya.

Didapat nilai sig variabel $\mathrm{X}$ sebesar 0,000 lebih kecil dari alpha 0,05 maka $\mathrm{H}_{0}$ ditolak artinya terdapat pengaruh signifikan $\mathrm{X}$ terhadap $\mathrm{Y}$.

\subsubsection{Interpretasi Output Analisis Regresi Linier Berganda}

Tabel 4. Model Summary Multiple Regression

\begin{tabular}{|c|c|c|c|c|}
\hline Model & $\mathrm{R}$ & R Square & $\begin{array}{c}\text { Adjusted R } \\
\text { Square }\end{array}$ & $\begin{array}{l}\text { Std. Error of the } \\
\text { Estimate }\end{array}$ \\
\hline 1 & $.744^{\mathrm{a}}$ & .554 & .521 & 2.28169 \\
\hline
\end{tabular}

a. Predictors: (Constant), Loan to Deposit Ratio, Return On Assets 
Pada tabel di atas nilai yang dianalisis untuk Analisis Regresi Linier Berganda adalah Adjusted R Square yang merupakan penyesuaian dari nilai R Square sebagaimana yang dijelaskan pada tahapan analisis regresi linier sederhana. Didapat nilai Adjusted R Square sebesar 0,521 artinya besarnya sumbangan variabel-variabel independen dalam mempengaruhi variabel dependen adalah sebesar $52,1 \%$ sedangkan sisanya $47,9 \%$ dipengaruhi oleh variabel lain.

Tabel 5. ANOVAa Multiple Regression

\begin{tabular}{|rl|r|r|r|r|r|}
\hline Model & & Sum of Squares & df & Mean Square & F & Sig. \\
\hline \multirow{3}{*}{1} & Regression & 174.634 & 2 & 87.317 & 16.772 & $.000^{\mathrm{b}}$ \\
& Residual & 140.565 & 27 & 5.206 & & \\
& Total & 315.199 & 29 & & & \\
\hline
\end{tabular}

a. Dependent Variable: Financing Performance

b. Predictors: (Constant), Loan to Deposit Ratio, Return On Assets

Melalui nilai sig pada tabel di atas dapat dianalisis pengujian secara simultan. Didapat nilai sig sebesar 0,000 artinya terdapat pengaruh secara simultan dari $\mathrm{X}_{1}$ dan $\mathrm{X}_{2}$ terhadap $\mathrm{Y}$ atau model penelitian fit.

Tabel 6. Coefficients ${ }^{\mathrm{a}}$ Multiple Regression

\begin{tabular}{|c|c|c|c|c|c|c|}
\hline \multirow{2}{*}{\multicolumn{2}{|c|}{ Model }} & \multicolumn{2}{|c|}{ Unstandardized Coefficients } & \multirow{2}{*}{$\begin{array}{c}\text { Standardized } \\
\text { Coefficients } \\
\text { Beta }\end{array}$} & \multirow[t]{2}{*}{ t } & \multirow[t]{2}{*}{ Sig. } \\
\hline & & B & Std. Error & & & \\
\hline \multirow{3}{*}{1} & (Constant) & 3.670 & 1.773 & & 2.070 & .048 \\
\hline & Return On Assets & .466 & .205 & .379 & 2.276 & .031 \\
\hline & Loan to Deposit Ratio & .562 & .211 & .443 & 2.662 & .013 \\
\hline
\end{tabular}

a. Dependent Variable: Financing Performance

Melalui nilai Constant dan coefficient variabel $\mathrm{X}_{1}$ dan $\mathrm{X}_{2}$ pada kolom $\mathrm{B}$, serta nilai sig variabel $\mathrm{X}_{1}$ dan $\mathrm{X}_{2}$ didapat persamaan regresi sebagai berikut:

$$
\mathrm{Y}=3,670+0,466 \mathrm{X}_{1}+0,562 \mathrm{X}_{2}
$$

Didapat nilai constant sebesar 3,670 artinya secara statistik tanpa adanya $\mathrm{X}_{1}$ dan $\mathrm{X}_{2}$ maka besarnya Y adalah 3,670.

Didapat nilai coefficient variabel $\mathrm{X}_{1}$ sebesar 0,466 artinya besarnya pengaruh $\mathrm{X}_{1}$ terhadap $\mathrm{Y}$ Cukup Kuat karena memiliki persentase sebesar $46,6 \%$ jika melihat interval pada tabel 3.

Didapat nilai coefficient variabel $\mathrm{X}_{2}$ sebesar 0,562 artinya besarnya pengaruh $\mathrm{X}_{2}$ terhadap $\mathrm{Y}$ Cukup kuat karena memiliki persentase sebesar 56,2\%.

Didapat nilai coefficient variabel $X_{1}$ positif artinya $X_{1}$ berpengaruh positif terhadap $Y$, semakin tinggi $\mathrm{X}_{1}$ maka $\mathrm{Y}$ semakin tinggi dan sebaliknya.

Didapat nilai coefficient variabel $X_{2}$ positif artinya $X_{2}$ berpengaruh positif terhadap $Y$, semakin tinggi $\mathrm{X}_{2}$ maka $\mathrm{Y}$ semakin tinggi dan sebaliknya.

Didapat nilai sig variabel $\mathrm{X}_{1}$ sebesar 0,031 lebih kecil dari alpha 0,05 maka $\mathrm{H}_{0}$ ditolak artinya terdapat pengaruh signifikan $\mathrm{X}_{1}$ terhadap $\mathrm{Y}$

Didapat nilai sig variabel $\mathrm{X}_{2}$ sebesar 0,013 lebih kecil dari alpha 0,05 maka $\mathrm{H}_{0}$ ditolak artinya terdapat pengaruh signifikan $\mathrm{X}_{2}$ terhadap $\mathrm{Y}$ 


\section{Daftar Pustaka}

Andi, S. (2011). Ekonometrika Terapan Teori Dan Aplikasi Dengan SPSS.

Hermina, T., \& Wufron, W. (2018). Aspek Permodalan, Kualitas Aset, Manajemen, Efisiensi, Likuiditas dan Sensitivitas Risiko Pasar dalam Menentukan Kinerja Keuangan Sektor Perbankan di Bursa Efek Indonesia. Jurnal Wacana Ekonomi, 17(1), 001-012. http://journal.uniga.ac.id/index.php/JA/article/view/220

Suharyadi, P. (2013). Statistika edisi 2.

Suliyanto, D. (2011). Ekonometrika Terapan: Teori dan Aplikasi dengan SPSS. Penerbit Andi: Yogyakarta.

Suliyanto, E. T. (2016). Teori dan Aplikasi dengan SPSS, Yogyakarta: CV. Andi Offset.

Zein, S. Z., Yasyifa, L. Y., Ghozi, R. G., Harahap, E., Badruzzaman, F. H., \& Darmawan, D. (2019). Pengolahan dan Analisis Data Kuantitatif Menggunakan Aplikasi SPSS. Teknologi Pembelajaran, 4(2). 